\title{
PENGEMBANGAN LEMBAR KERJA SISWA PEMBELAJARAN MATEMATIKA DENGAN PENDEKATAN KONSTRUKTIVISTIK MATERI POKOK TEOREMA PHYTAGORAS
}

\author{
Andang $^{1}$, Sowanto ${ }^{* 1}$, Saifullah ${ }^{1}$ \\ ${ }^{1}$ Dosen Pendidikan Matematika, STKIP Bima \\ *Email: sowantos@gmail.com
}

\begin{abstract}
ABSTRAK
Matematika merupakan mata pelajaran yang mendapat prioritas untuk dikembangkan karena matematika menjadi sarana yang dapat membantu siswa memecahkan masalah. Salah satu cara yang bisa dilakukan adalah mengembangkan perangkat pembelajaran. Tujuan penelitian ini adalah 1) menghasilkan lembar kerja siswa yang dikembangkan dengan pendekatan konstruktivistik dan valid serta bisa digunakan dalam proses pembelajaran, dan 2) mengetahui kualitas lembar kerja siswa berdasarkan respon siswa selama melakukan uji lapangan. Adapun prosedur pengembangan lembar kerja siswa mengacu pada model pengembangan 4D. Subjek penelitian adalah siswa kelas VIII pada SMPN 2 Kota Bima. Instrumen yang digunakan dalam penelitian ini terdiri dari lembar validasi dan lembar angket. Teknik analisis data yaitu dengan menggunakan analisis deskriptif, yang selanjutnya menggunakan kriteria kategori penilaian. Hasil penelitian menunjukan bahwa perangkat pembelajaran berbentuk lembar kerja siswa dengan pendekatan pembelajaran konstruktivistik pada materi teorema pythagoras di kelas VIII SMPN 2 Kota Bima yang berbentuk lembar kerja siswa adalah valid dengan kategori sangat baik, lembar kerja siswa setelah melalui tahap uji coba lapangan memenuhi kriteria kepraktisan dengan rata-rata aktivitas guru pada proses pembelajaran sebesar 4,48 atau berkategori sangat baik dan respon siswa positif yang ditunjukan dengan minat dan ketertarikannya dalam mengikuti pembelajaran. Lembar kerja siswa dinyatakan sudah efektif untuk diterapkan dalam proses pembelajaran dengan hasil tes belajar siswa sebesar 86,93 dan ketuntasan individu sebesar 89,12\%.
\end{abstract}

Kata Kunci: Lembar Kerja Siswa, Konstruktivistik, Teorema Pythagoras.

\begin{abstract}
Mathematics is a subject that gets priority to be developed because mathematics becomes a tool that can help students solve problems. One way that can be done is to develop learning tools. The purpose of this study was 1) to produce student worksheets that were developed with a constructivist and valid approach and could be used in the learning process, and 2) to determine the quality of student worksheets based on student responses during fieldwork. The procedure for developing student worksheets refers to the 4D development model. The subjects of the research were students of class VIII at SMPN 2 Kota Bima. The instruments used in this study consisted of validation sheets and questionnaire sheets. Data analysis technique is to use descriptive analysis, which then uses the category assessment criteria. The results showed that the learning tool in the form of student worksheets with a constructivist learning approach on the pythagorean theorem material in class VIII of SMPN 2 City of Bima in the form of student worksheets was valid with a very good category,
\end{abstract}


student worksheets after going through the field trial stage met practicality criteria with the average activity of the teacher in the learning process is 4.48 or categorized as very good and positive student responses shown by their interest and interest in participating in learning. Student worksheets have been declared effective to be applied in the learning process with the results of student learning tests of 86.93 and individual completeness of $89.12 \%$.

Keywords: Student worksheets, Constructivistic, Pythagorean Theorem.

\section{PENDAHULUAN}

Peningkatan mutu pendidikan termasuk pendidikan matematika merupakan suatu hal mutlak yang harus terus diupayakan. Pendidikan memegang peranan penting untuk meningkatkan kualitas sumber daya manusia. Pendidikan yang bermutu dapat memberikan bekal kepada siswa agar dapat memenuhi tuntutan hidup menyelesaikan permasalahanpermasalahan dalam kehidupan. Secara lebih luas, pendidikan yang bermutu dapat menyiapkan siswa untuk menjadi manusia masa depan yang menguasai ilmu pengetahuan dan teknologi. Penguasaan ilmu dan teknologi merupakan penopang perkembangan budaya dan kehidupan manusia baik di masa lalu, kini, dan masa yang akan datang.

Upaya untuk mencapai pendidikan yang optimal tidak dapat dipisahkan dari peningkatan mutu proses pembelajaran di kelas, yang salah satu komponen utamanya adalah guru. Proses pembelajaran matematika pada umumnya guru terlalu berkonsentrasi pada latihan menyelesaikan soal yang lebih bersifat prosedural mekanistis dari pada menanamkan pemahaman (Andang et all, 2018). Kualitas pembelajaran tergantung pada beberapa hal antara lain penguasaan guru terhadap materi (bahan ajar), cara guru menyajikan materi, cara guru memberikan penguatan, cara guru mengaktifkan siswa untuk berpartisipasi dan merasa terlibat dalam proses belajar, serta penguasaan guru terhadap evaluasi belajar. Berangkat dari hal tersebut, guru perlu menggunakan perangkat pembelajaran yang menggambarkan kemampuan guru karena melalui perangkat pembelajaran yang disusun dengan baik membantu guru untuk dapat mengelola pembelajaran dengan baik.

Mengembangkan perangkat pembelajaran dengan berorientasi pada suatu pendekatan pembelajaran dapat menjadi salah satu cara untuk melaksanakan pembelajaran yang efektif. Oleh karena itu, pendekatan pembelajaran yang dipilih harus dapat menumbuhkan kemampuan dasar yang dimiliki siswa sehingga dapat menemukan sendiri hal-hal yang baru. Siswa memperoleh kesempatan untuk mempelajari materi pelajaran 
melalui serangkaian kegiatan sehingga dapat menemukan dan mengembangkan pengetahuan yang diperolehnya.

Pengembangan perangkat pembelajaran diperlukan mengingat masih banyak guru mengajar dengan menggunakan metode lama, dimana guru bertindak sebagai penyampai informasi, guru menganggap diri tahu segalanya, sementara siswa hanya dapat mengetahui setelah mendapatkan informasi dari gurunya. Keadaan tersebut menjadi semakin parah dengan sumber bahan ajar yang digunakan hanya bersumber dari buku teks pegangan guru sementara siswa ditugaskan untuk mendengarkan dan mencatat apa yang disampaikan guru. Hal tersebut menjadi persoalan penting dalam proses pembelajaran sebagaimana disebutkan Andang (2017) bahwa kelemahan dasar mengajar guru di sekolah karena guru mengajar dengan menggunakan metode-metode lama, kurang kreatif dan inovatif sehingga menjadikan siswa tidak mampu menggunakan keterampilan berpikirnya.

Salah satu pendekatan yang akhir-akhir ini menjadi perhatian penting di kalangan peneliti pendidikan sains dalam rangka meningkatkan sumber daya yang berkualitas adalah pembelajaran dengan pendekatan konstruktivistik. Menurut Rachanah (2009) Salah satu model pembelajaran yang berkembang saat ini adalah pembelajaran berorientasi konstruktivistik yang terdiri dari: Model Pembelajaran Langsung (Direct Instruction), Pembelajaran Kooperatif (Cooperative Learning, dengan variasi Student Teams Achievement Division (STAD), Jigsaw, Investigasi Kelompok, Think Pair Share, Numbered Head Together), Pengajaran Berdasarkan Masalah (Problem Based Instruction), Pengajaran dan Pembelajaran Kontekstual (Contextual Teaching and Learning), Pembelajaran Model Diskusi Kelas, Model Pembelajaran Inkuiri, Strategi Belajar PQ4R, dan Strategi Belajar Peta Konsep (Concept Mapping). Pendekatan konstruktivistik pada dasarnya menekankan bahwa pengetahuan harus dibangun sendiri oleh siswa berdasarkan pengetahuan yang telah dimiliki sebelumnya. Pada pembelajaran konstruktivistik, siswa mengkonstruksi pengetahuan dan pemahamannya sendiri sesuai dengan skema yang dimilikinya sebagai implikasi dari interaksi dengan orang lain dan lingkungannya.

Uraian di atas menjadi dasar yang melatarbelakangi pengembangan perangkat pembelajaran yang terdiri dari Rencana Pembelajaran (RP) dan Lembar Kerja Siswa (LKS) dengan berorientasi pendekatan konstruktivistik pada materi teorema pythagoras. Alasan 
pemilihan materi teorema pythagoras karena kenyataan di lapangan menunjukkan bahwa kemampuan siswa memecahkan masalah masih sangat lemah. Oleh karena itu, perlu adanya upaya pengembangan perangkat pembelajaran materi teorema pythagoras sehingga memudahkan siswa untuk melakukan pemecahan masalah dan meningkatkan kemampuan berpikirnya. Dengan demikian, penelitian ini dimaksudkan untuk menghasilkan perangkat pembelajaran berupa RPP dan LKS yang dikembangkan dengan menggunakan pendekatan konstruktivistik pada materi teorema Pythagoras. Perangkat pembelajaran ini dapat dijadikan sebagai pegangan guru maupun sumber belajar siswa agar dapat mengikuti proses pembelajaran secara aktif. Dengan demikian, hasil akhir dari pembelajaran dalam meningkatkan kemamampuan siswa dalam memecahkan masalah dapat dicapai.

\section{Pembelajaran dengan Pendekatan Kontruktivitas}

Model pembelajaran yang menekankan bagaimana membelajarkan siswa merupakan acuan teori belajar konstruktivistik yang menganggap bahwa orang hanya dapat mengerti dan mengetahui sesuatu yang telah dikonstruksikannya sendiri. Melalui pembelajaran konstruktivisme, peserta didik ditempa sehingga memahami teori, latihan dan dapat mengaplikasikan teori dan latihan tersebut dalam dunia nyata di sekolah (Amidi et all, 2014). Penerapan pendekatan konstruktivisme bertujuan agar belajar tidak hanya sekedar menghafal rumus tetapi perlu adanya kegiatan untuk membangun pengetahuan dan pemahaman melalui aktivitas yang dilakukan sendiri oleh peserta didik (Fitri, 2017). Piaget merupakan psikolog pertama yang menggunakan filsafat konstruktivisme dalam proses pembelajaran. Menurut Piaget perubahan kognitif seseorang dapat terjadi melalui proses asimilasi dan akomodasi, dan proses ini terus berjalan dalam diri seseorang.

Asimilasi adalah suatu proses di mana seseorang menggabungkan suatu objek baru atau peristiwa baru ke dalam skemata (struktur kognitif) yang telah dimilikinya. Setiap orang secara terus menerus mengembangkan proses asimilasi sesuai dengan perkembangan pengetahuan yang dimilikinya. Asimilasi juga dapat dikatakan sebagai proses yang dilakukan seseorang untuk mengadaptasikan dirinya dengan lingkungan baru sehingga pengertiannya tentang sesuatu terus berkembang. Sedangkan akomodasi merupakan proses di mana seseorang mengakomodasi skemata yang dimiliki dengan situasi yang cocok. Skemata menunjukkan taraf pengertian seseorang tentang dunia sekitarnya, dan terbentuk dari pengalamannya sepanjang waktu. 
Inti teori pembelajaran dengan pendekatan konstruktivis adalah bahwa manusia atau siswa mengkonstruksi pengetahuan dari pengalamannya sendiri sesuai dengan skemata yang dimilikinya sebagai implikasi dari interaksi dengan orang lain dan lingkungannya. Lebih lanjut menurut filosofi konstruktivis, bahwa siswa harus secara aktif menyusun sendiri konsep-konsep baru di dalam struktur kognitifnya. Agar pembelajaran dapat berlangsung perlu dikembangkan keterampilan berfikir siswa dan sedapat mungkin pembelajaran dilaksanakan secara bermakna dengan mengkaitkan pembelajaran dengan kehidupan nyata siswa. Bertolak dari pandangan konstruktivis tersebut, maka pembelajaran matematika sebaiknya lebih menekankan kepada siswa untuk mengkonstruksi sendiri pengetahuan matematika yang dipelajari melalui konteks atau budaya dan dikaitkan dengan pengetahuan yang telah dimilikinya.

Dalam konstruktivis, proses pembelajaran sangat menekankan pada keaktifan siswa dalam membangun sendiri pengetahuannya. Menurut kaum konstruktivis, belajar adalah proses mengasimilasi dan menghubungkan pengalaman atau bahan yang sedang dipelajari dengan pengalaman yang telah dimiliki seseorang sehingga pengertiannya berkembang. Sedangkan mengajar menurut konstruktivis bukanlah kegiatan memindahkan pengetahuan dari guru ke siswa, namun merupakan kegiatan yang memberikan kesempatan kepada siswa untuk membangun sendiri pengetahuannya (Fitri, 2017). Disini terlihat jelas bahwa peran guru dalam konstruktivis hanya sebagai mediator dan fasilitator yang membantu agar proses belajar siswa dapat berjalan dengan baik.

\section{Perangkat Pembelajaran}

Perangkat pembelajaran adalah sekumpulan sumber belajar yang dapat membantu proses pembelajaran. Perangkat pembelajaran dibuat oleh guru sebagai persiapan untuk menyampaikan materi pelajaran yang meliputi materi yang akan diajarkan, soal yang diberikan, waktu yang diperlukan serta kegiatan-kegiatan yang akan dilakukan oleh guru dan siswa selama kegiatan pembelajaran berlangsung. Pada pembelajaran matematika tentang teorema pythagoras akan diwujudkan dalam bentuk Lembar Kerja Siswa (LKS). Lembar Kerja Siswa merupakan lembaran yang diberikan kepada perserta didik untuk kegiatan percobaan. Sebagai media pembelajaran, LKS dapat digunakan untuk mengaktifkan siswa dalam pembelajaran. Selain itu, LKS juga dapat memberikan kesempatan yang cukup luas kepada siswa untuk mandiri. Ditinjau dari bentuk 
kegiatannya, LKS dapat dibedakan menjadi dua yaitu: LKS eksperimen dan LKS non ekpperimen. LKS eksperimen adalah LKS yang berisikan sejumlah petunjuk dan pertanyaan yang harus dilakukan siswa saat melakukan percobaa atau eksperimen. Sedangkan LKS non eksperimen adalah LKS yang berisi pertanyaan yang dapat membantu siswa menguasai bahan ajar yang mereka pelajari.

\section{METODE PENELITIAN}

Penelitian ini berusaha mengembangkan perangkat pembelajaran yang berupa rencana pembelajaran dan lembar kerja siswa yang mengacu pada pendekatan konstruktivis, sehingga penelitian ini termasuk jenis penelitian pengembangan. Penelitian pengembangan adalah penelitian yang dilakukan dengan cara mengadakan percobaan dan penyempurnaan terhadap suatu sistem. Untuk mengembangkan perangkat pembelajaran tersebut, peneliti mengumpulkan data tentang pembelajaran dengan pendekatan konstruktivis dan juga data tentang materi teorema pythagoras.

Untuk pengembangan perangkat pembelajaran pada tulisan ini, peneliti mengacu pada model pengembangan 4D yang diperkenalkan oleh Thiagarajan S., Dorothy S. Semmel, dan Melvyn I. Semmel seperti pada gambar dibawah ini.

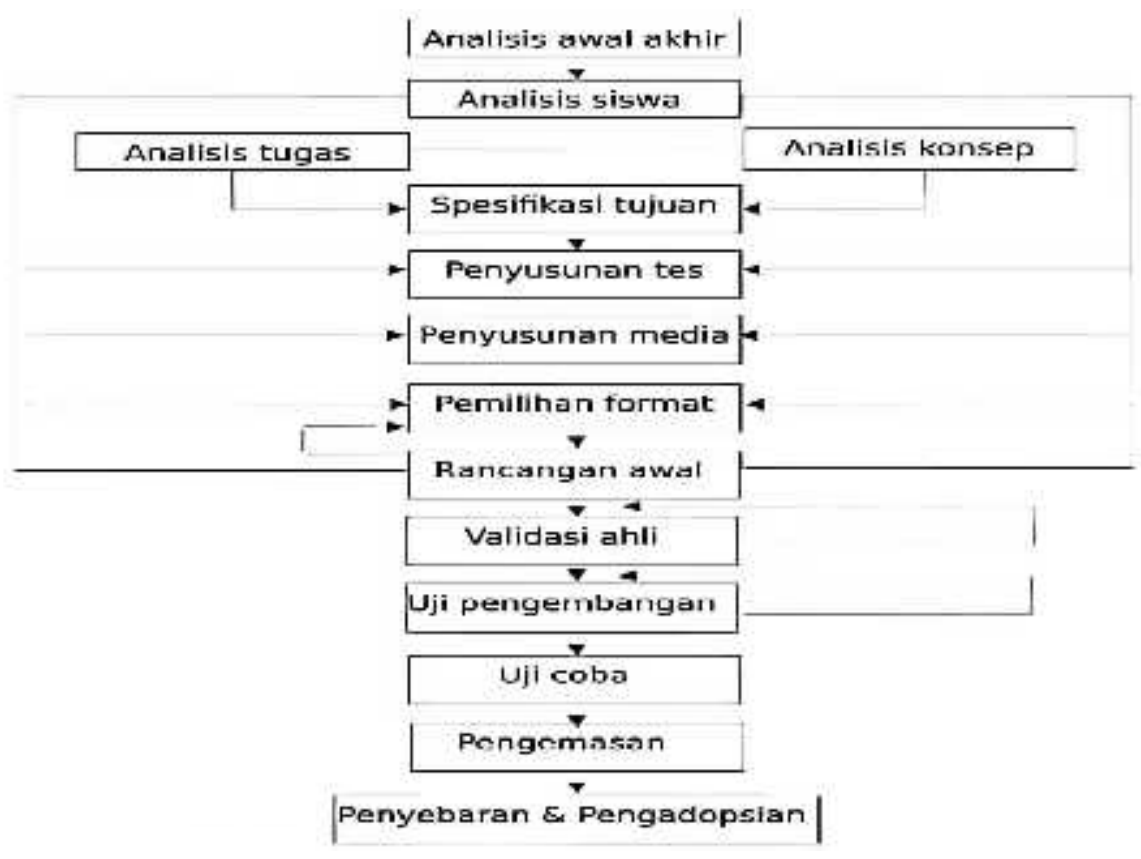

Gambar 1. Model Pengembangan Pembelajaran 4-D 
Instrumen yang digunakan dalam penelitian ini terdiri dari lembar validasi perangkat pembelajaran dan lembar angket. Lembar validasi perangkat pembelajaran diperlukan untuk menilai produk yang dikembangkan berupa LKS untuk dapat menentukan standar kepraktisan dan efektivitas. Sedangkan lembar angket diperlukan untuk menilai produk pengembangan LKS dengan menggunakan kolom check list meliputi daftar penilaian dan skala penilaiannya serta lembar komentar, tanggapan, kritik dan saran dari validator.

Data validasi perangkat pembelajaran dikumpulkan dengan menggunakan lembar validasi perangkat pembelajaran. Para validator menilai setiap perangkat pembelajaran dengan cara memberikan nilai pada setiap aspek yang tersedia dalam lembar validasi dengan cara membubuhkan tanda cek $(\sqrt{ })$ pada kolom yang sesuai. Teknik pengumpulan data pada saat uji coba perangkat pembelajaran ada dua macam yakni observasi dan angket. Observasi dilakukan untuk melihat aktivitas peserta didik dan melihat penggunaan perangkat pembelajaran oleh guru untuk mencocokkan informasi yang diberikan oleh guru dengan keadaan yang sebenarnya (Fitri, 2017). Tes hasil belajar siswa diberikan kepada siswa setiap akhir pertemuan. Tes dilakukan untuk mengetahui pemahaman siswa terhadap materi yang telah diberikan.

Untuk menganalisis data pengembangan perangkat pembelajaran maka teknik yang digunakan adalah analisis deskriptif (Andang, et al, 2018). Data yang dianalisis adalah 1) analisis data validasi. Data hasil validasi para ahli untuk masing-masing format perangkat pembelajaran dianalisis dengan mempertimbangkan penilaian, masukan, komentar dan saransaran dari validator. Hasil analisis tersebut dijadikan sebagai pedoman untuk revisi perangkat pembelajaran. Tingkat validitas masing-masing perangkat pembelajaran ditentukan dengan melibatkan hasil penilaian semua validator. Analisis dilakukan teradap semua butir penilaian yang telah dilakukan oleh masing-masing validator, dengan membuat rekapitulasi skor dan kemudian menentukan rata-rata tiap aspek penilaian berdasarkan rata-rata setiap butir penilaian semua validator. Selanjutnya menentukan rata-rata total berdasarkan rata-rata setiap aspek penilaian. 2) Analisis data kepraktisan. Analisis ini ditentukan berdasarkan penilaian validator dengan kriteria-kriteria yaitu dapat digunakan tanpa revisi, dapat digunakan dengan revisi kecil, dapat digunakan dengan revisi besar, dan belum dapat digunakan masih memerlukan konsultasi. 3) Analisis angket. Analisis data yang digunakan untuk mengolah data perolehan dari angket validasi produk pengembangan bersifat Statistik deskriptif. Data 
kuantitatif dari tiap-tiap item instrumen dihitung dengan menggunakan teknik analisis nilai rata-rata.

\section{HASIL DAN PEMBAHASAN}

\section{Tahap Pendefenisian (Define)}

Pada tahap ini dilakukan untuk menentukan dan mengidentifikasi hal-hal yang diperlukan dalam mengembangkan perangkat pembelajaran, dalam hal ini Rencana Pembelajaran dan Lembar Kerja Siswa (LKS). Hasil identifikasi tersebut sebagai berikut:

\section{a. Identifikasi Awal-Akhir}

Pada tahap identifikasi ini, peneliti melakukan wawancara dengan guru matematika SMPN 2 Kota Bima dan ditemukan bahwa pelaksanaan kegiatan pembelajaran yang telah dilakukan masih berpusat pada guru (teacher oriented). Metode mengajar masih dominan menggunakan metode ceramah, Tanya jawab, dan pemberian tugas. Pada saat disinggung mengenai pendekatan konstruktivistik dalam pembelajaran, ternyata guru tersebut belum begitu memahaminya dan belum pernah menggunakannya dalam proses pembelajaran. Selanjutnya, peneliti menyinggung tentang perangkat pembelajaran yang digunakan guru dalam pembelajara didapatkan bahwa perangkat pembelajaran yang selama ini digunakan untuk mengajar bersumber dari buku paket matematika.

\section{b. Identifikasi Siswa}

Identifikasi siswa yang dimaksud adalah mengenal karakteristik siswa yang menjadi sasaran ujicoba perangkat pembelajaran, siswa kelas VIIIB SMPN 2 Kota Bima. Karakteristik siswa yang di identifikasi mencakup latar belakang pengetahuan siswa dan sikap secara umum terhadap topik pembelajaran. Materi Teorema Pythagoras disebut sebagai materi yang cukup sulit bagi siswa karena ketika ditanya tentang gambaran umum dari materi tersebut, siswa belum mampu menjawabnya dengan baik.

\section{c. Identifikasi Materi Pembelajaran}

Identifikasi materi pembelajaran bertujuan untuk mengetahui bagian-bagian pokok bahan ajar yang akan dipelajari siswa. Dalam kurikulum 2013, materi teorema Pythagoras yang diajarkan pada kelas VIII semester genap memiliki sub bahasan lengkapnya sebagai 
berikut: 1) Konsep teorema pythagoras, 2) Bentuk konsep teorema pythagoras, 3) Penerapan teorema pythagoras, 4) Menyelesaikan teorema pythagoras, 5) Menemukan hubungan antar panjang sisi pada segitiga khusus, 6) Menyelesaikan model matematika yang berkaitan dengan Pythagoras, 7) Penggunaan teorema Pythagoras pada suatu permasalahan, 8) Penggunaan teorema Pythagoras pada suatu kehidupan nyata, dan 9) Penggunaan teorema Pythagoras untuk menyelesaikan permasalahan yang dibuat pada tugas proyek yang telah diberikan.

\section{d. Identifikasi Tugas}

Berdasarkan pada identifikasi materi ajar diperoleh tugas pokok yang harus dikerjakan atau diselesaikan siswa sebagai berikut: 1) memahami penggunaan Teorema Pythagoras untuk menyelesaikan berbagai masalah, 2) mampu menyusun bentuk Pythagoras, 3) memahami penyelesaian Pythagoras, 4) Menyelesaikan model matematika yang berkaitan dengan Pythagoras, dan 5) Menyelesaikan model matematika dari masalah nyata yang berkaitan dengan Pythagoras.

\section{e. Spesifikasi Tujuan}

Spesifikasi tujuan didasarkan pada kompetesi dasar yang harus dikuasai siswa yaitu Memahami Teorema Pythagoras melalui alat peraga dan penyelidikan berbagai pola bilangan, dan Menggunakan Teorema Pythagoras untuk menyelesaikan berbagai masalah. Dengan demikian tujuan pembelajaran dapat dirumuskan melalui tujuan pembelajaran khsusus pada materi teorema pythagoras yang dinyatakan dalam bentuk tingkah laku siswa sebagai berikut: 1) siswa dapat memahami Teorema Pythagoras melalui alat peraga dan penyelidikan berbagai pola bilangan, dan 2) siswa mampu menggunakan Teorema Pythagoras untuk menyelesaikan berbagai masalah terutama dalam kehidupan sehari-hari.

\section{Tahap Perancangan (Design)}

Tahap perancangan merupakan tahap merancang perangkat pembelajaran versi awal atau perangkat pembelajaran yang belum direvisi yang meliputi rencana pembelajaran dan lembar kerja siswa. Tahap perancangan terdiri dari pemilihan format dan rancangan awal perangkat pembelajaran.

\section{a. Pemilihan Format}


Pemilihan format dalam perangkat pembelajaran ini diperlukan untuk mendesain format rencana pembelajaran dan format lembar kerja siswa (LKS). Format untuk mendesain rencana pembelajaran adalah ketersediaan tempat untuk menuliskan identitas RPP, kompetensi inti, kompetensi dasar, indikator, materi pembelajaran, kegiatan pembelajaran, penilaian hasil pembelajaran, dan media alat dan sumber pembelajaran. Sementara format untuk mengembangkan LKS adalah ketersediaan tempat untu menuliskan identitas LKS, alokasi waktu, kompetensi dasar indikator dan materi pembelajaran, dan kegiatan-kegiatan siswa dengan menyelesaikan soal-soal yang berkaitan dengan materi pembelajaran.

\section{b. Rancangan Awal}

Rancangan awal pada perangkat pembelajaran meliputi rancangan rencana pembelajaran dan rancangan awal LKS. Rencana pembelajaran dan LKS dikembangkan berorientasi pada pembelajaran dengan pendekatan konstruktivistik. Rencana pembelajaran disusun untuk 6 (enam) kali pertemuan dengan masing-masing materi sebagai berikut: pertemuan ke-1: 1) Konsep teorema pythagoras, 2) Bentuk konsep teorema pythagoras. Pertemuan ke-2: 1) Penerapan teorema pythagoras, 2) Menyelesaikan teorema pythagoras. Pertemuan ke-3: Menemukan hubungan antar panjang sisi pada segitiga khusus. Pertemuan ke-4: Menyelesaikan model matematika yang berkaitan dengan Pythagoras. Pertemuan ke-5: 1) Penggunaan teorema Pythagoras pada suatu permasalahan, 2) Penggunaan teorema Pythagoras pada suatu kehidupan nyata. Pertemuan ke-6: Penggunaan teorema Pythagoras untuk menyelesaikan permasalahan yang dibuat pada tugas proyek yang telah diberikan. Sedangkan LKS dikembangkan dengan memasukan uraian materi dan/atau kegiatan-kegiatan siswa dengan mengerjakan soal-soal materi teorema pythagoras. Setiap pertemuan dapat terdiri dari 1 (satu) atau lebih kegiatan serta beberapa contoh soal yang dikerjakan siswa. Pada LKS yang dikembangkan diberikan penekanan dengan mengikuti format atau tahapan pembelajaran konstruktivistik yaitu 1) Pengaktifan pengetahuan yang sudah ada, 2) Perolehan pengetahuan baru, 3) Pemahaman pengetahuan, 4) Menerapkan pengetahuan dan pengalaman yang diperoleh, dan 5) Melakukan refleksi.

\section{Tahap Pengembangan (Develop)}

a. Penilaian Ahli (Expert Appraisal) 
Setelah dihasilkan perangkat pembelajaran hasil pengembangan maka perlu ditindaklanjuti untuk divalidasi sebelum dilakukan ujicoba lapangan oleh para ahli. Langkah ini bertujuan untuk menentukan valid atau tidaknya suatu perangkat pembelajaran untuk di ujicobakan. Nama-nama dan pekerjaan penilai ahli diantaranya: Ibu Sri Aryaningsih, M.Pd dan Bapak Murtalib, M.Pd, keduanya merupakan ahli matematika dan bekerja sebagai dosen. Sedangkan Ibu Maryati, M.Pd merupakan guru matematika yang ada pada SMPN 2 Kota Bima. Validasi dilakukan terhadap perangkat pembelajaran yakni rencana pembelajaran dan lembar kerja siswa. Adapun kriteria penilaian validitas dapat ditentukan seperti tertera pada tabel 1 berikut.

Tabel 1. Jenjang Kriteria Penilaian Validitas (Nurdin, 2007)

\begin{tabular}{cc}
\hline Rentang Nilai Kuantitatif & Kategori Kualitatif \\
\hline $4,5 \leq \mathrm{M} \leq 5$ & Sangat Valid \\
$3,5 \leq \mathrm{M} \leq 4,5$ & Valid \\
$2,5 \leq \mathrm{M} \leq 3,5$ & Cukup valid (revisi kecil) \\
$1,5 \leq \mathrm{M} \leq 2,5$ & Kurang valid (revisi besar) \\
$\mathrm{M} \leq 1,5$ & Tidak Valid (revisi total) \\
\hline
\end{tabular}

Penilaian ahli terhadap draf lembar kerja siswa meliputi format pengembangan materi pelajaran, bahasa yang digunakan, ilustrasi, dan kebenaran dan kelogisan isi. Hasil validasi terhadap perangkat pembelajaran sebagai berikut:

Penilaian ahli terhadap draf rencana pembelajaran dan lembar kerja siswa meliputi format pengembangan materi pelajaran, bahasa yang digunakan, ilustrasi, dan kebenaran dan kelogisan isi. Hasil validasi terhadap perangkat pembelajaran sebagai berikut:

1) Penilaian Ahli terhadap Rencana Pembelajaran

Hasil validasi rencana pembelajaran oleh ahli selanjutnya dilakukan rekap. Rekapitulasi dan kesimpulan hasil validasi dapat ditunjukan melalui tabel 2. berikut.

Tabel 2. Rekapitulasi Hasil Validasi Rencana Pembelajaran

\begin{tabular}{ccccccc}
\hline Validasi & \multicolumn{5}{c}{ Penilaian RPP } \\
\cline { 2 - 7 } Ahli & Pertem.I & Pertem. II & Pertem. III & Pertem. IV & Pertem. V & Pertem. VI \\
\hline V-1 & 2,3 & 3,0 & 3,5 & 3,0 & 3,6 & 3,2 \\
V-2 & 2,4 & 3,2 & 3,6 & 2,8 & 3,8 & 2,9 \\
V-3 & 2,6 & 2,9 & 3,5 & 2,9 & 3,6 & 3,3 \\
Rata-Rata & 2,4 & 3,0 & 3,5 & 2,9 & 3,6 & 3,1 \\
\hline \multirow{2}{*}{ Kategori } & Kurang & Cukup & \multirow{2}{*}{ Valid } & Cukup & \multirow{2}{*}{ Valid } & Cukup \\
& valid & Valid & & Valid & & Valid \\
\hline
\end{tabular}

Keterangan: $\mathrm{V}=$ Validator 
Berdasarkan tabel 2. diatas dapat disimpulkan bahwa pada rencana pembelajaran pertemuan I dinyatakan kurang valid. Pada pertemuan II, IV, dan V dinyatakan cukup valid. Sedangkan pada pertemuan III dan V dinyatakan valid, namun demikian terdapat sedikit revisi walaupun tidak signifikan untuk mendapatkan tingkat validitas yang tinggi.

Selanjutnya rekapitulasi penilaian umum validator terhadap draf rencana pembelajaran yang dikembangkan dapat ditunjukan seperti tabel 4.4 berikut.

Tabel 3. Rekapitulasi Hasil Penilaian Umum Validator

\begin{tabular}{cccccccc}
\hline \multirow{2}{*}{ No } & \multirow{2}{*}{ Kualifikasi } & \multicolumn{5}{c}{ Banyaknya Validator Memberikan Penilaian } \\
\cline { 3 - 8 } & RPP 1 & RPP II & RPP III & RPP IV & RPP V & RPP VI \\
\hline \multirow{4}{*}{1} & SB & 1 & - & 1 & - & 2 & 1 \\
& B & - & 1 & 2 & 1 & 1 & 1 \\
& C & 1 & 2 & 1 & 2 & - & 1 \\
& KB & 1 & 1 & - & - & - & - \\
& SK & - & - & - & - & - & - \\
2 & TR & - & 1 & 2 & 1 & 2 & 1 \\
& SR & 1 & 1 & 1 & - & 1 & 2 \\
& BR & 2 & 1 & - & 2 & - & - \\
& PK & - & - & - & - & - & - \\
\hline
\end{tabular}

Keterangan:

$\begin{array}{ll}\mathrm{SB}=\text { Sangat Baik } & \mathrm{TR}=\text { Dapat digunakan tanpa revisi } \\ \mathrm{B}=\text { Baik } & \mathrm{SR}=\text { Dapat digunakan dengan sedikit revisi } \\ \mathrm{C}=\text { Cukup } & \mathrm{BR}=\text { Dapat digunakan dengan banyak revisi } \\ \mathrm{K}=\text { Kurang } & \mathrm{PK}=\text { Belum dapat digunakan, perlu konsultasi } \\ \mathrm{SK}=\text { Sangat Kurang } & \end{array}$

Berdasarkan Tabel 3. diatas dapat disimpulkan bahwa pada rencana pembelajaran pertemuan I perlu dilakukan revisi besar. Pada pertemuan II, IV, dan V dilakukan revisi kecil. Sedangkan pada pertemuan III dan V dinyatakan dapat digunakan dengan tanpa revisi namun perlu memperhatikan catatan validator. Dari hasil penilaian dan masukan validator, selanjutnya peneliti melakukan revisi atau memperbaiki draf rencana pembelajaran. Adapun bagian-bagian yang direvisi adalah pada RPP I sampai VII, perbaikan dilakukan dengan menuliskan materi pembelajaran pada setiap kali pertemuan, memperjelas kegiatan pembelajaran sesuai pendekatan konstruktivistik, pada kegiatan inti pembelajaran ditentukan menjadi tiga fase yaitu fase eksplorasi, fase klarifikasi, dan fase aplikasi, dan pada penilaian hasil pembelajaran siswa agar disesuaikan dengan kurikulum 2013 yang meliputi penilaian sikap spiritual, sikap sosial, pengetahuan, dan keterampilan. 
Setelah dilakukan revisi, peneliti kembali melakukan konsultasi dan validasi kepada ahli. Hasil validasi rencana pembelajaran oleh ahli selanjutnya dilakukan rekap. Rekapitulasi dan kesimpulan hasil validasi dapat ditunjukan melalui tabel 4. berikut.

Tabel 4. Rekapitulasi Hasil Validasi Rencana Pembelajaran Hasil Revisi

\begin{tabular}{ccccccc}
\hline Validasi & \multicolumn{5}{c}{ Penilaian RPP } \\
\cline { 2 - 7 } Ahli & Pertem.I & Pertem. II & Pertem. III & Pertem. IV & Pertem. V & Pertem.VI \\
\hline V-1 & 3,9 & 4,0 & 4,4 & 4,3 & 4,6 & 4,7 \\
V-2 & 3,8 & 4,2 & 4,6 & 4,5 & 4,8 & 4,9 \\
V-3 & 4,0 & 4,1 & 4,6 & 3,5 & 4,7 & 4,6 \\
Rata-Rata & 3,9 & 4,1 & 4,5 & 4,4 & 4,7 & 4,7 \\
Kategori & \multirow{2}{*}{ Valid } & \multirow{2}{*}{ Valid } & Sangat & Valid & Sangat & Sangat \\
& & & Valid & & Valid & Valid \\
\hline
\end{tabular}

Keterangan: $\mathrm{V}=$ Validator

Berdasarkan tabel 4. diatas dapat disimpulkan bahwa pada rencana pembelajaran pertemuan I, II, dan IV dinyatakan valid. Sementara pada pertemuan III, V, dan VI dinyatakan sangat valid. Dengan demikian perangkat pembelajaran berbentuk rencana pembelajaran dinyatakan memenuhi tingkat kevalidan dan dapat digunakan pada ujicoba lapangan.

Sementara hasil rekapitulasi penilaian umum validator terhadap draf rencana pembelajaran yang dikembangkan dengan memperhatikan banyaknya validator memberikan penilaian menunjukan bahwa rencana pembelajaran I, II, dan IV berada dalam kategori baik rencana pembelajaran III, V, dan VI dalam kategori sangat baik sehingga draf rencana pembelajaran tersebut dapat digunakan tanpa revisi pada proses pembelajaran kelas VIII SMPN 2 Kota Bima.

2) Penilaian ahli terhadap Lembar Kerja Siswa

Perangkat pembelajaran yang dinilai oleh validator adalah Lembar Kerja Siswa. Hasil validasi Lembar Kerja Siswa oleh ahli selanjutnya dilakukan rekap. Rekapitulasi dan kesimpulan hasil validasi dapat ditunjukan melalui tabel 5 berikut.

Tabel 5. Rekapitulasi Hasil Validasi Lembar Kerja Siswa

\begin{tabular}{|c|c|c|c|c|c|c|}
\hline \multirow{2}{*}{$\begin{array}{l}\text { Validasi } \\
\text { Ahli }\end{array}$} & \multicolumn{6}{|c|}{ Penilaian LKS } \\
\hline & Pertem.I & Pertem. II & $\begin{array}{l}\text { Pertem. } \\
\text { III }\end{array}$ & $\begin{array}{l}\text { Pertem. } \\
\text { IV }\end{array}$ & $\begin{array}{l}\text { Pertem. } \\
\text { V }\end{array}$ & $\begin{array}{l}\text { Pertem. } \\
\text { V }\end{array}$ \\
\hline $\mathrm{V}-1$ & 2,1 & 2,2 & 2,6 & 3,6 & 3,7 & 3,4 \\
\hline $\mathrm{V}-2$ & 2,2 & 2,4 & 2,6 & 3,6 & 3,8 & 3,1 \\
\hline $\mathrm{V}-3$ & 2,4 & 2,3 & 2,7 & 3,5 & 3,6 & 3,3 \\
\hline Rata-Rata & 2,2 & 2,3 & 2,6 & 3,5 & 3,6 & 3,2 \\
\hline
\end{tabular}




\begin{tabular}{ccccccc}
\hline Kategori & $\begin{array}{c}\text { Kurang } \\
\text { Valid }\end{array}$ & $\begin{array}{c}\text { Kurang } \\
\text { Valid }\end{array}$ & $\begin{array}{c}\text { Cukup } \\
\text { Valid }\end{array}$ & Valid & Valid & $\begin{array}{c}\text { Cukup } \\
\text { Valid }\end{array}$ \\
\hline
\end{tabular}

Keterangan: $\mathrm{V}=$ Validator

Berdasarkan tabel 5 diatas dapat disimpulkan bahwa pada Lembar Kerja Siswa pertemuan I dan II dinyatakan kurang valid. Pada pertemuan III, dan VI dinyatakan cukup valid. Sedangkan pada pertemuan IV dan V dinyatakan valid, namun demikian terdapat sedikit revisi walaupun tidak signifikan untuk mendapatkan tingkat validitas yang tinggi.

Selanjutnya rekapitulasi penilaian umum validator terhadap draf lembar kerja siswa yang dikembangkan dapat ditunjukan seperti tabel 6 berikut.

Tabel 6. Rekapitulasi Hasil Penilaian Umum Validator

\begin{tabular}{|c|c|c|c|c|c|c|c|}
\hline \multirow[t]{2}{*}{ No } & \multirow[t]{2}{*}{ Kualifikasi } & \multicolumn{6}{|c|}{ Banyaknya Validator Memberikan Penilaian } \\
\hline & & LKS 1 & LKS II & LKS III & LKS IV & LKS V & LKS VI \\
\hline \multirow[t]{5}{*}{1} & SB & - & - & - & 1 & 1 & - \\
\hline & $\mathrm{B}$ & - & - & 1 & 2 & 2 & 1 \\
\hline & $\mathrm{C}$ & 1 & - & 2 & - & - & 2 \\
\hline & $\mathrm{KB}$ & 1 & 2 & - & - & - & - \\
\hline & SK & 1 & 1 & - & - & - & - \\
\hline \multirow[t]{4}{*}{2} & TR & - & - & - & 2 & 2 & - \\
\hline & SR & 1 & 1 & 2 & 1 & 1 & 2 \\
\hline & BR & 2 & 2 & 1 & - & - & 1 \\
\hline & PK & - & - & - & - & - & - \\
\hline
\end{tabular}

Keterangan:

$\begin{array}{ll}\mathrm{SB}=\text { Sangat Baik } & \text { TR }=\text { Dapat digunakan tanpa revisi } \\ \mathrm{B}=\text { Baik } & \mathrm{SR}=\text { Dapat digunakan dengan sedikit revisi } \\ \mathrm{C}=\text { Cukup } & \mathrm{BR}=\text { Dapat digunakan dengan banyak revisi } \\ \mathrm{K}=\text { Kurang } & \mathrm{PK}=\text { Belum dapat digunakan, perlu konsultasi } \\ \mathrm{SK}=\text { Sangat Kurang } & \end{array}$

Berdasarkan tabel 6 diatas dapat disimpulkan bahwa pada rencana pembelajaran pertemuan I perlu dilakukan revisi besar. Pada pertemuan II, IV, dan V dilakukan revisi kecil. Sedangkan pada pertemuan III dan V dinyatakan dapat digunakan dengan tanpa revisi namun perlu memperhatikan catatan validator. Dari hasil penilaian dan masukan validator, selanjutnya peneliti melakukan revisi atau memperbaiki draf rencana pembelajaran. Adapun bagian-bagian yang direvisi adalah pada RPP I sampai VII, perbaikan dilakukan dengan menuliskan materi pembelajaran pada setiap kali pertemuan, memperjelas kegiatan pembelajaran sesuai pendekatan konstruktivistik, pada kegiatan inti pembelajaran ditentukan menjadi tiga fase yaitu fase eksplorasi, fase klarifikasi, dan fase aplikasi, dan pada penilaian 
hasil pembelajaran siswa agar disesuaikan dengan kurikulum 2013 yang meliputi penilaian sikap spiritual, sikap sosial, pengetahuan, dan keterampilan.

Setelah dilakukan revisi, peneliti kembali melakukan konsultasi dan validasi kepada ahli. Hasil validasi lembar kerja siswa oleh ahli selanjutnya dilakukan rekap. Rekapitulasi dan kesimpulan hasil validasi dapat ditunjukan melalui tabel 7 berikut.

Tabel 7. Rekapitulasi Hasil Validasi Lembar Kerja Siswa Hasil Revisi

\begin{tabular}{|c|c|c|c|c|c|c|}
\hline \multirow{2}{*}{$\begin{array}{l}\text { Validasi } \\
\text { Ahli }\end{array}$} & \multicolumn{6}{|c|}{ Penilaian LKS } \\
\hline & Pertem.I & Pertem. II & $\begin{array}{l}\text { Pertem. } \\
\text { III }\end{array}$ & $\begin{array}{l}\text { Pertem. } \\
\text { IV }\end{array}$ & $\begin{array}{l}\text { Pertem. } \\
\text { V }\end{array}$ & $\begin{array}{l}\text { Pertem. } \\
\text { V }\end{array}$ \\
\hline V-1 & 3,8 & 4,3 & 4,5 & 4,6 & 4,6 & 4,8 \\
\hline $\mathrm{V}-2$ & 3,7 & 4,2 & 4,7 & 4,5 & 4,7 & 4,8 \\
\hline $\mathrm{V}-3$ & 3,8 & 4,2 & 4,6 & 4,8 & 4,9 & 4,9 \\
\hline Rata-Rata & 3,7 & 4,2 & 4,6 & 4,6 & 4,7 & 4,8 \\
\hline Kategori & Valid & Valid & $\begin{array}{c}\text { Sangat } \\
\text { Valid }\end{array}$ & $\begin{array}{c}\text { Sangat } \\
\text { Valid }\end{array}$ & $\begin{array}{c}\text { Sangat } \\
\text { Valid }\end{array}$ & $\begin{array}{c}\text { Sangat } \\
\text { Valid }\end{array}$ \\
\hline
\end{tabular}

Keterangan: $\mathrm{V}=$ Validator

Berdasarkan tabel 7 diatas dapat disimpulkan bahwa pada lembar kerja siswa pertemuan I, dan II dinyatakan valid. Sementara pada pertemuan III, IV, V, dan VI dinyatakan sangat valid. Dengan demikian perangkat pembelajaran berbentuk lembar kerja siswa dinyatakan memenuhi tingkat kevalidan dan dapat digunakan pada ujicoba lapangan.

Sementara hasil rekapitulasi penilaian umum validator terhadap draf lembar kerja siswa yang dikembangkan dengan memperhatikan banyaknya validator memberikan penilaian menunjukan bahwa lembar kerja I dan II berada dalam kategori baik dan lembar kerja siswa III, IV, V, dan VI berada dalam kategori sangat baik sehingga draf lembar kerja siswa tersebut dapat digunakan tanpa revisi pada proses pembelajaran kelas VIII SMPN 2 Kota Bima.

\section{b. Uji Coba Keterbacaan}

Setelah perangkat pembelajaran divalidasi oleh ahli, kegiatan selanjutnya adalah melakukan ujicoba keterbacaan. Uji coba perangkat pembelajaran ini bertujuan untuk penyempurnaan perangkat pembelajaran sebelum digunakan. Rencana pembelajaran diberikan kepada guru mitra yang akan melakukan ujicoba di lapangan yaitu ibu Maryati, M.Pd selaku guru matematika kelas VIIIA SMPN 2 Kota Bima. Sedangkan untuk lembar kerja siswa diberikan kepada siswa kelas $\mathrm{VIII}_{\mathrm{B}}$ SMPN 2 Kota Bima yang memiliki karakteristik hampir sama dengan siswa kelas VIII $_{\mathrm{A}}$ SMPN 2 Kota Bima. Berdasarkan hasil ujicoba keterbacaan, 
terdapat beberapa perbaikan sebagai hasil masukan, namun tidak terlalu signifikan, diantaranya: 1) rencana pembelajaran agar format dan pemilihan bahasanya diperbaiki berdasarkan pada ejaan yang disempurnakan dan bersifat baku, dan 2) pada lembar kerja siswa agar memperhatikan karakteristik pendekatan pembelajaran konstruktivistik dan dilakukan pengembangan lembar kerja siswa mengacu pada pendekatan tersebut.

\section{c. Uji Coba Lapangan}

Perangkat pembelajaran yang telah direvisi berdasarkan masukan atau penilaian pada ujicoba keterbacaan, selanjutnya diujicobakan pada subyek penelitian kelas VIII $_{\mathrm{A}}$ SMP Negeri 2 Kota Bima. Perangkat pembelajaran yang diujicoba adalah rencana pembelajaran, lembar kerja siswa, dan instrument penelitian berbentuk tes hasil belajar. Uji coba pada tahap pengembangan ini adalah ujicoba perangkat pembelajaran yang dilakukan oleh guru matematika kelas VIII $_{\text {A }}$ SMP Negeri 2 Kota Bima yaitu Ibu Maryati, M.Pd. Pada tahap ini dilibatkan 2 orang pengamat/observer dengan tugas yang berbeda. Seorang mengamati aktivitas siswa dan seorang lagi bertugas mengamati kemampuan guru dalam mengelola pembelajaran. Sedangkan tugas peneliti sekaligus sebagai pengamat umum yang mengamati semua aktivitas di kelas selama pembelajaran berlangsung. Dari hasil uji coba perangkat pembelajaran, diperoleh data aktivitas siswa, data kemampuan guru mengelola pembelajaran, data pretes dan postes, dan data respon siswa.

1) Observasi Aktivitas Siswa

Pengamat yang melakukan pengamatan aktivitas siswa saat ujicoba perangkat pembelajaran 2 orang. Satu orang mengamati 2 kelompok yakni pengamat I (P-I) mengemati kelompok 1 dan 2. Sedangkan pengamat II (P-II) mengamati kelompok 3,4, dan 5. Kategori pengamatan menyesuaikan dengan pendekatan pembelajaran konstruktivistik yang terdiri dari: 1) pengaktifan pengetahuan yang sudah ada, 2) perolehan pengetahuan baru, 3) pemahaman pengetahuan, 4) menerapkan pengetahuan dan pemahaman yang diperoleh, dan 5) melakukan refleksi, serta 7) perilaku siswa yang tidak relevan dengan KBM. Data aktivitas siswa selama pembelajaran diperoleh skor keidealan sebesar 89,98\%, yang berati bahwa aktivitas siswa mengikuti pembelajaran konstruktivistik berada dalam kategori sangat efektif.

2) Observasi Pengelolaan Pembelajaran

Pengamat yang bertugas mengamati pengelolaan pembelajaran yang dilakukan guru saat ujicoba perangkat pembelajaran berjumlah 2 orang. Hasil pengamatan kemampuan guru 
mengelola pembelajaran matematika dengan pembelajaran konstruktivistik ditemukan bahwa terdapat beberapa aspek pengamatan yang mencapai kriteria baik dan sangat baik dari kemampuan guru sebelumnya. Hal tersebut nampak dari kemampuan guru Guru mengajukan pertanyaan awal kepada siswa tentang materi yang di ajarkan, guru memperkenalkan konsep teorema phytagoras dan bentuk teorema phytagoras, siswa merumuskan kembali pengetahuan mereka tentang konsep teorema phytagoras dan bentuk teorema phytagoras, guru memberikan masalah untuk dikerjakan siswa melalui lembar kerja siswa, guru mengevaluasi dan menilai penguasaan pengetahuan dan pemahaman yang diperoleh, antusias siswa maupun guru. Ratarata kemampuan guru dalam mengelola pembelajaran konstruktivistik sebesar 4,48 dan berada pada kotegori sangat baik.

\section{3) Respon Siswa}

Berdasarkan angket respon siswa setelah mengikuti pembelajaran pada materi teorema pythagoras dengan pendekatan konstruktivistik diperoleh hasil yaitu terdapat 96\% siswa menyukai cara mengajar guru, $88 \%$ siswa menyukai suasana pembelajaran, lebih dari $92 \%$ siswa menyatakan berminat mengikuti pembelajaran selanjutnya menggunakan pembelajaran konstruktivistik, 90\% siswa tertarik dengan bahasa yang digunakan, dan 87\% siswa menyatakan kebaruan terhadap komponen pembelajaran yang digunakan. Dengan demikian, dapat simpulkan bahwa respon siswa terhadap komponen pembelajaran matematika dengan pendekatan konstruktivistik adalah positif dan perangkat pembelajaran yang dihasilkan merupakan perangkat pembelajaran draf akhir dan sudah dapat digunakan.

4) Hasil Belajar

Tes hasil belajar diujikan untuk mengetahui ketuntasan siswa setelah mengikuti proses pembelajaran dengan menggunakan pendekatan konstruktivistik berbantuan lembar kerja siswa. Berdasarkan pada uji validitas didapatkan bahwa semua item soal tes pemahaman sebanyak 4 (empat) nomor dinyatakan valid. Sedangkan pada uji reliabelitas dinyatakan reliabel dengan nilai sebesar 0,812 dan berkategori tinggi. Setelah dilakukan uji lapangan ditemukan data hasil belajar siswa materi teorema pythagoras rata-rata sebesar 86,93 dengan ketuntasan individu sebesar 89,12\%.

Dengan demikian, perangkat pembelajaran yang dikembangkan berbentuk rencana pembelajaran dan lembar kerja siswa sudah siap untuk digunakan pada siswa SMP kelas VIII baik pada SMPN 2 Kota Bima maupun pada sekolah-sekolah lainnya. 


\section{KESIMPULAN}

Berdasarkan hasil penelitian dan pembahasan diperoleh simpulan sebagai berikut: 1) Perangkat pembelajaran dengan pendekatan pembelajaran konstruktivistik pada materi teorema pythagoras di kelas VIII yang terdiri dari rencana pembelajaran dan lembar kerja siswa adalah valid dengan kategori sangat baik setelah dilakukan beberapa kali revisi. Hal ini menunjukan bahwa perangkat yang dikembangkan dapat digunakan sebagai sumber belajar. 2) Perangkat pembelajaran dengan pendekatan pembelajaran konstruktivistik pada materi teorema pythagoras di kelas VIII yang terdiri dari rencana pembelajaran dan lembar kerja siswa memenuhi kriteria kepraktisan setelah melalui tahap uji coba lapangan. Hal tersebut karena perangkat yang dikembangkan dapat digunakan tanpa revisi, rata-rata persentase aktivitas guru pada proses pembelajaran sebesar 4,48 atau berkategori sangat baik, dan respon siswa positif yang ditunjukan dengan minat dan ketertarikannya yang tinggi dalam mengikuti pembelajaran. 3) Perangkat pembelajaran dengan pendekatan pembelajaran konstruktivistik pada materi teorema pythagoras di kelas VIII yang terdiri dari rencana pembelajaran dan lembar kerja siswa sudah efektif. Hal tersebut dapat dilihat dari hasil tes belajar siswa dengan rata-rata sebesar 86,93 dengan ketuntasan individu sebesar 89,12\%.

\section{REKOMENDASI}

Perangkat pembelajaran yang dikembangkan dengan pendekatan pembelajaran konstruktivistik pada materi teorema pythagoras di kelas VIII yang berbentuk lembar kerja siswa telah memenuhi uji kevalidan, kepraktisan, dan keefektifannya sehingga dapat direkomendasikan kepada guru-guru yang mengajar di kelas VIII agar menggunakan perangkat ini karena dapat membantu siswa meningkatkan hasil belajarnya dan memiliki ketertarikan dan minat yang tinggi dalam mengikuti proses pembelajarannya. Pada penelitian ini hanya mengembangkan perangkat berbentuk lembar kerja siswa, sehingga kepada peneliti lain agar dapat mengembangkan bentuk perangkat lain yang berupa modul atau buku ajar siswa, atau dengan menggunakan sub materi yang lain.

\section{UCAPAN TERIMAKASIH}

Terlaksananya kegiatan penelitian ini tidak terlepas dari dukungan semua pihak yang telah membantu baik dalam bentuk materi maupun inmateri. Kepada STKIP Bima dan Kemenristekdikti saya ucapkan terimakasih dan penghargaan yang setinggi-tingginya atas 
bantuan dana penelitian melalui skema penelitian dosen pemula. Melalui penelitian ini, saya mendapatkan pengalaman meneliti dengan proses yang sungguh-sungguh dan hasil yang dipertanggungjawabkan.

\section{REFERENSI}

Andang, Irfan, \& Mulyadin, E. (2017). Strategi Pembelajaran. Yogyakarta: Deepublis

Andang, Hadi, A. M., \& Wirahmad, I. (2018). Pengembangan Perangkat Pembelajaran Cooperative Integrated Reading And Composition Untuk Meningkatkan Pemahaman Geometri. AKSIOMA: Jurnal Matematika dan Pendidikan Matematika, 9(2), 23-35. Di akses dari http://dx.doi.org/10.26877/aks.v9i2.2837

Andang. (2018). Meningkatkan hasil belajar matematika melalui penerapan metode kerja kelompok dengan bantuan tutor sebaya pada siswa kelas viii smp negeri 1 donggo tahun pelajaran 2013-2014. Di akses dari https://osf.io/preprints/inarxiv/t6rz9/.

Amidi, Amidi \& Waluya, Stevanus \& Hindarto, Nathan. (2014). Pembelajaran Matematika Konstruktivistik Berbasis Humanistik Berbantuan E-Learning Pada Materi Segitiga Kelas VII. Kreano: Jurnal Matematika Kreatif-Inovatif. 5. 10.15294/kreano.v5i2.4034.

Fitri, R. (2017). Pengembangan Perangkat Pembelajaran Berbasis Pendekatan Konstruktivisme Untuk Meningkatkan Kemampuan Pemahaman Konsep Pada Materi Persamaan Lingkaran. Jurnal JNPM (Jurnal Nasional Pendidikan Matematika) September 2017 Vol. 1, No. 2, Hal. 242. Tersedia pada: httpjurnal.unswagati.ac.idindex.phpJNPMarticleview5620.

Rachanah, Ratnaningsih, Mulyani, Purnamasari, \& Excalanti. (2009). Pengembangan Model Pembelajaran Berorientasi Konstruktivistik Untuk Meningkatkan Kualitas Pembelajaran Akuntansi di SMA. Jurnal Penelitian Vol.10 No.2 Oktober 2009. Tersedia pada: httpwww.jurnal.upi.edufileNanih_Rachanah.pdf. 